\title{
Cash flow ratios and financial performance: A comparative study
}

\author{
Somnath Das*
}

Rabindra Mahavidyalaya, Champadanga, Hooghly - 712401, India

\begin{tabular}{|c|c|}
\hline$\overline{C H R O N ~ I ~ C ~ L E ~}$ & ABSTRACT \\
\hline $\begin{array}{l}\text { Article history: } \\
\text { Received April 1, } 2018 \\
\text { Received in revised format May } \\
112018 \\
\text { Accepted June } 262018 \\
\text { Available online } \\
\text { June } 262018 \\
\text { Keywords: } \\
\text { Cash flow ratios } \\
\text { Sufficiency ratios } \\
\text { Efficiency ratios } \\
\text { Profitability, liquidity }\end{array}$ & $\begin{array}{l}\text { Cash flow ratios are generally prepared from cash flow statement as per AS- } 03 \text {. It is helpful } \\
\text { for financial users including shareholders, management, accountants, auditors and investors to } \\
\text { get the relevant information regarding its financial resources for a certain period. Currently } \\
\text { cash flow ratios are randomly used instead of traditional ratios due to its wideness and } \\
\text { acceptability. In credit rating and forecasting the failure of an organization, cash flow ratios are } \\
\text { very much relevant. In this study, we considered different companies from different sectors. } \\
\text { From the study, it is clear that the liquidity and solvency position of the companies are moderate } \\
\text { whereas the companies maintained low profitability. The efficiency ratios and sufficiency } \\
\text { ratios of the companies selected in this study provide us a new look of financial judgement. In } \\
\text { our study, we selected three companies from FMCG and Pharmaceuticals sectors. We used the } \\
\text { data for a period of } 10 \text { years from } 2004 \text { to } 2013 \text { financial years. }\end{array}$ \\
\hline
\end{tabular}

O 2017 by the authors; licensee Growing Science, Canada.

\section{Introduction}

The prosperity of an organization depends on the monitoring and management of funds in and out of an organization for a specific timeframe. Cash flow is the most common financial reports (Halen, 2002), which affect the profitability and survival of the organization. For analyzing the profitability and risk of the organization, traditional ratios are not always helpful. For that, we need additional information, which is provided by the cash flow statement. During the past two decades, cash flow has played an immense role in credit rating, decision making, fraud examining etc. Cash flow ratios are more reliable indicators of liquidity than the balance sheet and statement because it excludes static data as well as non-cash items like depreciation and amortization. Creditors and lenders are frequently using cash flow ratios instead of traditional ratios because cash flow ratios provide more information regarding the company's ability to meet its payment commitments rather than traditional ratios. Cash flow ratios provide dynamic picture of the company (Mills \& Yamamura, 1998)

Sometimes business has negative cash flows. Due to negative cash flows, it is not possible for business to pay off its current debts. Therefore, cash flow ratios with traditional ratios portray a better conclusion of the business (Carslaw \& Mills, 1991). Cash flow ratios are not very popular though cash flow statement as per AS-3 is mandatory. Still now, researchers, managers are not frequently using cash

* Corresponding author.

E-mail address: somnath211@gmail.com (S. Das) 
flow ratios. They are giving too much importance on traditional ratios like current ratio (Bodie et al., 2004). In this study we selected two sectors vide, FMCG and Pharmaceuticals. We made a comparative analysis among them with the help of Cash flow ratios.

\section{Literature Review}

Barth et al. (2001) and Stammerjohan and Nassiripour (2001) used a modest model of time series in a bid to put to test the relationship between future cash flows and the accrual elements of earnings of a firm. From the studym they reached a conclusion that each of the individual aspects of accrual accounting of the earnings yielded divergent information as regards the future projections of the cash flows of a firm. In contrast, Stammerjohan and Nassiripour (2001), attempted to reproduce the research study that had been undertaken by Barth et al. (2001). They opined that the two studies yielded evidence to the fact that models that bore a correlation with both total accruals and cash flows were more likely to forecast future cash flows of a firm with an enhanced level of assurance, when compared with those models whose basis was just the earnings of a company. However, the study that Stammerjohan and Nassiripour undertook was seen to provide weak evidence when it was related to the issue of predictive models that utilize both cash flows and accrual earnings. As per the findings of research studies that have been carried out lately, the significance of operating cash flows has been stated, in as far as the evaluation of a credit risk is concerned (Ahmed et al., 2002). By instinct, it may be expected that a creditor would be more interested in an evaluation of cash flows because of business operations. This is due to the fact that a majority of the agencies that deal with the rating of credit, for instance, Standard and Poor's, make use of cash flow as a credit quality measure (Ahmed et al., 2002; Das, 2017; Epstein, \& Jermakowicz, 2008).

According to the findings of a survey accomplished by Jones (1997), several users of financial statements and the group that was surveyed was made up of investors, managers, and creditors. The objective of the survey was to assess what information contained in a financial statement could be of prime importance to these individuals. Based on responses of the creditors, whose members were increasingly higher than that of the managers and the investors, they claimed that they relied on the applications of the operating cash flows for purposes of arriving at sustainable decision. DeFond and Hung (2003), used an illustration of the trend by a financial analyst to release forecast on operating cash flows and indicated that the cash flows play a significant role in as far as the forecasting of the future performance of a company. From the study, it has been observed that analysts have a tendency to release forecasts on operating cash flows at a time when it has become quite clear that earnings per share could not prove reliable in terms of evaluating the future of a firm. Therefore, with high volatility of earnings and with poor financial health signifies the distress and it require immediate assessment of cash flows.

There are many studies on the level of quality where firms in a given economy tend to impact greatly on the valuation of such companies. This is based on several indicators of measurements, such as Tobin's Q (Gompers et al., 2003; Bebchuk \& Cohen, 2005; Cremers \& Nair 2005). Such studies pinpoint fundamental governance measures, which emphasize the connection with the valuation of a firm. These measures include an annual selection of the members of the board to a corporation, option re-pricing, and the level of attendance to the annual general meetings by the various directors of a firm. Cash flows considered as a useful piece of information, especially as a way of knowing how cash, a vital resource in a business entity, comes into a firm and how it is utilized (Rose, 2007; Fabozzi et al., 2002; Macve, 1997). The use of cash flow is also important from the view point of professional that manages a business entity. In addition, the rest of the stakeholders of the company who will be affected by the utilization of cash flow ratios as well as the planning and analysis tools. Giacomino and Mielke (1993) used cash flow ratios as benchmark of the companies in regard to their performance. These ratios are of two types Efficiency ratios and sufficiency ratios. In other studies, two or three ratios have been used but in this study we used Efficiency ratios, Sufficiency ratios along with liquidity ratios, solvency ratios and profitability ratios. 


\section{Objectives of the Study}

In this research, we established the relationship between Cash Flow from Operations (CFO) and Current Ration (CR), Inventory Turnover ratio (ITR), Debtors Turnover Ratio (DTR) and Interest Coverage Ratio (ICR). Profitability, Size of the Organization and Cumulative Profitability can influence the Cash flow from operations of the organization. In this study, profitability has been measured by Return on Net worth (RONW), Size of the Organization has been represented through the amount equal to the log value of total assets. Shareholders fund has been selected in this study as cumulative profitability, which consists of equity share capital and reserve surpluses. We used the log value for getting the continuously compounded relation or growth of companies' assets and shareholders' fund. For analyzing the data statistical tools like Arithmetic Mean, Standard Deviation, Coefficient of Variation, Ranking etc. and statistical techniques like Pearson's Simple Correlation analysis and Multiple Regression analysis and statistical test like ' $t$ ' test have been applied in appropriate places. Cash Flow Ratio analysis is not an easy procedure. For determining cash flow ratios, we have to consider the nature and type of business as well as the judgement of the manager. Cash flow ratio analysis is to some extent, risk analysis. More specifically, the objectives of the study are stated below.

1. To measure the different efficiency ratios from two different sectors,

2. To measure the different sufficiency ratios from two different sectors,

3. To measure the performance of the selected companies from two different sectors,

4. To measure the relationship between CFO and CR, ITR, DTR, and ICR, and

5. To judge the influence of RONW, Size of the Organization and Shareholders fund on CFO.

\subsection{Data and Sample Design}

Six companies from two sectors (Pharmaceuticals and FMCG) have been selected taking three companies from each sector. The data of the selected companies for the period 2004 to 2013 used in this study have been taken from the secondary sources i.e. Capitaline Corporate Database of Capital market Publishers (I) Ltd., Annual Report of selected companies and Money Control.Com website. Mumbai. For the purpose of our study, different companies from two sectors are selected following the purposive sampling procedure.

\subsection{Research Methodology}

From the past studies, it is clear that the measurement of performance through conventional ratios is no longer feasible in the competitive environment. In this study, we used Liquidity ratio, Solvency ratio and Profitability ratios by using Cash flow from operating activity.

Liquidity Ratio: It is the ratio of Cash flow from operating activity to Current Liabilities. Operating cash flow to current liability is an alternative to current ratio. The formula of this ratio is as follows,

$$
\text { Liquidity Ratio }=\frac{\text { Operating cash flow }}{\text { Current Liability }}
$$

This ratio allows us to tell if a business is generating enough cash from operations to meet these liabilities. Higher the ratio, better the liquidity position of the company.

Solvency Ratio: It is the ratio of Cash flow from operating activity to Total Liabilities. This ratio provides an indication of a company's ability to cover total debt with its yearly cash flow from operation. The formula of this ratio is 
Solvency Ratio $=\frac{\text { Operating cash flow }}{\text { Total Liabilities }}$.

The higher the percentage of the ratio, the better the company's ability to carry its total debts.

Solvency Ratio: It is the ratio of Cash flow from operating activity plus Interest to Interest. It is a combination of both debt ratio and profitability ratio. It is used to determine how easily a company can pay interest on outstanding debt. The formula of this ratio is as follows,

$$
\text { Solvency Ratio }=\frac{\text { Operating cash flow }+ \text { Interest }}{\text { Interest }} .
$$

It measures the margin of safety a company has for paying interest during a given period, which a company needs in order to survive future financial hardship. Interest coverage ratio, less than one indicates that the company is not generating sufficient revenues to satisfy its interest expenses.

Profitability Ratio: It is the ratio of Operating cash flow to total revenue. This ratio gives an idea of the company's ability to turn sales into cash. The formula of this ratio is as follows,

$$
\text { Profitability Ratio }=\frac{\text { Operating cash flow }}{\text { Total Revenue }} \text {. }
$$

In the operating section of the cash flow statement, the net income figure is adjusted for non-cash charges and increase/decrease in the working capital items in company's current assets and liabilities. The greater the amount of operating cash flow, the better the position of the organization. There is no standard guideline for the cash flow margin.

Profitability Ratio: It is the ratio of Operating cash flow to Net income. Instead of P/E ratio we can use this ratio. The formula of this ratio is as follows,

$$
\text { Profitability Ratio }=\frac{\text { Operating cash flow }}{\text { Net Income }}
$$

When this ratio rises above one, it is indicative of a strong ability to fund it activities through generation of operating cash flow. In other words, a higher ratio means that the firm's earnings are of a higher quality. This ratio remains below one for an extended period of time could be an indication that the company will need to raise money to fund its operations. In this research study we also used two special types of ratios. They are efficiency ratios, sufficiency ratios (Wells, 2005; Pereiro, 2002; Paterson \& Drake, 1999).

Efficiency Ratios: Efficiency ratios can be defined as a standard of measurement for the quality of a particular businesses' receivables and the efficiency by which that business utilizes its assets. In this study we used three efficiency ratios. They are Cash flow to sales ratio, Operations index and Cash flow returns on assets.

Cash flow to Sales Ratio: This ratio gives the cash flow as a percentage of the sales ratio. Here sales mean net sales. With the help of following formula we can compute the said ratio.

$$
\text { Cash flow to Sales ratio }=\frac{\text { Operating Cash Flow }}{\text { Net Sales Revenue }} \text {. }
$$

The ratio determines the capacity of the company to incur cash from net operations, which can be equated to the sales amount generated by the company. 
Operations index: The operations index compares the operating cash flow with the profit of the company before payment of income tax. The formula for the ratio is below:

$$
\text { Operations Index }=\frac{\text { Operating Cash Flow }}{\text { Operating profit before Income Tax }}
$$

The operating cash flow takes into account the changes in working capital such that the disclosures (or the lack thereof) determine the oversight or the attention of the company of subject in the quality of their business decisions that will turn potential earnings.

Cash flow returns on assets: The formula displays the amount of cash that a company is generating in proportion to its asset. This calculation can also be done directly using the financial statements of the company through the formula:

$$
\text { Cash flow return on Assets }=\frac{\text { Operating Cash Flow }}{\text { Total Assets }} \text {. }
$$

The indication of the Cash Flow return on Assets allows us to assess the company's business decisions regarding capitalization.

Sufficiency ratio: Sufficiency can be defined as the capacity of the business to settle it financial requirements. Given the definition of sufficiency, a cash flow sufficiency ratio can be construed as the ability of a particular company to generate a sufficient amount of funding (Cash) to meet the company's basic obligations. These include the payment of the company's long term debts, acquisition of assets and the payment of share holders' dividends.

Long-term debt payment: Long term debt repayment formulas monitor the adequacy of the flow of cash to settle the long term financial liabilities and payments of the instalments of the company's debt obligations on a yearly basis. The formula of this ratio is as follows,

$$
\text { Long Term Debt repayment }=\frac{\text { Longterm Debt Payments }}{\text { Operating Cash Flow }}
$$

The greater the ratio deemed from the above calculation, it is concluded that the company has the capacity to withstand the possibility of debt forfeiture.

Dividend Payout: This ratio is found by dividing the dividend per share by the earnings per share and is expressed as a percentage. We can calculate the said ratio with the help of following formula,

$$
\text { Dividend Payout Ratio }=\frac{\text { Dividends per Share }}{\text { Earnings Per Share }}
$$

The ratio used by investors to determine if the company will generate a return on their investments for long term duration. A ratio of greater than one indicates that existing dividends are at a level that cannot be sustained over a long term.

Cash flow adequacy ratio: This ratio measures how sufficiently a company meets its current commitments, particularly in the area of assets acquisition, payment of dividend and payment of financial obligations. The formula is shown below:

$$
\text { Cash Flow Adequacy Ratio }=\frac{\text { Operating Cash Flow }}{\text { Fixed Assets Long- term Debt paid }+ \text { Cash Dividend }} \text {. }
$$


From past experience, a ratio exceeding the value of 1 indicates that the company has good financial health, while a ratio less than 1 might indicate that the company has liquidity problems.

Reinvestment Ratio: This ratio tells us that how quickly the company ploughing back its cash into business. The formula is as follows,

$$
\text { Reinvestment Ratio }=\frac{\text { Inc. in fixed assets }+ \text { Inc. in WC }}{\text { Net Income }+ \text { Non cash Exp. }- \text { Non cash Sales }- \text { Div. }} \text {. }
$$

Depreciation-amortization Ratio: This ratio depicts the real state of the profitability of the company. The formula of this ratio is as under,

$$
\text { Depreciation- amortization Ratio }=\frac{\text { Depreciation expenses }+ \text { Amortization Expenses }}{\text { Operating Cash Flow }} .
$$

Debt coverage ratio: The Debt Coverage formula can also be termed as Debt Service Coverage Ratio $(D S C R)$. This ratio measures the capability of the company to pay the annual interest and principal on its debt. Obviously, the ratio will come into picture only for companies who actually rely on debts. This ratio is the least analyzed one, as most of the companies did not have this component.

$$
\text { Debt Coverage Ratio }=\frac{\text { Total Operating Income }}{\text { Total Debt Service }}
$$

\section{Findings of the Study}

The objective of this research was to establish the relationship between profitability and Cash Flows from Operating Activities of the selected companies under study. Findings of the study indicated that there was significant relationship between profitability and cash flow from Operating Activity of the selected companies under study and they are presented in Appendix 1. From Table 1 it is observed that on the basis of average liquidity ratio, Marico ranked first and it followed by Britannia, Lupin etc. On the other hand, from the point of view of coefficient of variation HUL scored first and it followed by Marico, Britannia etc. From overall point of view i.e. on the basis of average and COV, Marico ranked first and it followed by Britannia, HUL, Lupin etc. Though importance should be given to all the companies selected under this study to improve their liquidity.

Table 2 depicted that the average solvency ratio of HUL is highest and it followed by Marico, Britannia etc. On the other hand, from the point of view of coefficient of variation HUL is scored first and it followed by Cipla, Britannia etc. From overall point of view i.e. on the basis of both, i.e. average and $\mathrm{COV}$, HUL ranked first and it followed by Britannia, Marico etc.

Table 3 stated that on the basis of average solvency ratio, HUL ranked first and it followed by Cipla, Marico etc. On the other hand, from the point of view of coefficient of variation Marico is scored first and it followed by Lupin, Britannia etc. From overall point of view i.e. on the basis of both, i.e. average and COV, Marico ranked first and it followed by Cipla, HUL etc.

On the basis of average Profitability ratio it is depicted from Table 4 that HUL ranked first and it followed by Lupin, Cipla etc. On the other hand, from the point of view of coefficient of variation HUL scored first and it followed by Cipla, Britannia etc. From overall point of view i.e. on the basis of, average and COV, HUL ranked first and it followed by Cipla, Lupin etc. 
From Table 5 it is found that on the basis of average Profitability ratio, HUL ranked first and it followed by Lupin, Cipla etc. On the other hand, from the point of view of coefficient of variation HUL scored first and it followed by Cipla, Britannia etc. From overall point of view i.e. on the basis of, average and COV, HUL ranked first and it followed by Cipla, Lupin etc.

From Table 6 we observed that on the basis of average Cash flow to Sales ratio, HUL obtained the first position among the selected companies and it followed by Lupin, Cipla etc. From Coefficient of variation point of view HUL scored the first place and it followed by Cipla, Britannia etc. On the basis of average and COV HUL is the best and it followed by Cipla, Lupin etc.

From Table 7 we found that on the basis of average Operations index ratio, Alchemist ranked first and it followed by Lupin, Marico etc. On the other hand, from the point of view of coefficient of variation HUL is scored first and it followed by Cipla, Lupin etc. From overall point of view i.e. on the basis of, average and COV, HUL, ranked first and it followed by Marico, Lupin, Alchemist etc. Though importance should be given to all the companies selected under this study to improve their profitability.

Cash flow returns on assets ratio exhibits that the amount of cash that a company is generating in proportion to its assets. The ratio indicates the company's business decision regarding capitalization. On the basis of average Cash flow returns on assets ratio it is observed from Table 8 that HUL ranked first and it followed by Marico, Britannia etc. On the other hand, from the point of view of coefficient of variation, HUL is scored first and it followed by Cipla, Marico etc. From overall point of view i.e. on the basis of, average and COV, HUL ranked first and they followed by Marico, Britannia etc. Though importance should be given to all the companies selected under this study to improve their decisions regarding capitalization.

Sufficiency ratio can be defined as the capacity of the business to settle its financial requirements. Given the definition of sufficiency, a cash flow sufficiency ratio can be constructed as the ability of a particular company to generate a sufficient amount of funding to meet the company's basic obligations.

Long-term debt payment ratio is considered as an indicator of a company's gearing and leverage relation to its capacity to pay off its long term indebtness. Greater ratio signifies higher chances of getting debt forfeiture of the company. It allows investors, management and other interested parties to measure the company's strength in facing inducement of current debts that is act as the measurement of the company's safety net.

From Table 9 we found that the average Long term Debt Payment ratio of HUL is highest and it followed by Cipla, Britannia etc. On the other hand, from the point of view of coefficient of variation, Lupin is scored first and it followed by Cipla, Britannia etc. From overall point of view i.e. on the basis of, average and COV, Cipla ranked first and it followed by Lupin, HUL, Britannia etc. Though importance should be given to all the companies selected under this study to improve their debt management.

Dividend Pay-out ratio is used to determine whether the company will generate a return on their investments for long term duration. A ratio greater than one, indicates that the existing dividends are at a level that cannot be sustained over a long term. However, if a small portion of earnings are being paid back as dividends, one can assume that the remaining cash is being ploughed back into operations, which should result in an increase in the stock price.

On the basis of average Dividend Pay Out ratio in Table 10, it is observed that Alchemist ranked first and it followed by HUL, Britannia etc. On the other hand, from the point of view of coefficient of variation, HUL is scored first and it followed by Cipla, Lupin etc. From overall point of view i.e. on the basis of, average and COV, HUL ranked first and it followed by Britannia, Alchemist etc. Though 
importance should be given to all the companies selected under this study to improve their refinancing decision.

Cash flow adequacy ratio is the ratio of operating cash flow to fixed assets plus long term debt paid plus cash dividend. This ratio measures the current commitments, particularly in the area of assets acquisition, pay out of dividend and fixed financial obligations. If the ratio is greater than one it signifies that the company has good financial health, while the ratio less than one might indicate that the company has liquidity problem.

From Table 11 it is depicted that on the basis of average Cash Flow Adequacy ratio, HUL ranked first and it followed by Britannia, Marico etc. On the other hand, from the point of view of coefficient of variation, HUL is scored first and it followed by Cipla, Marico etc. From overall point of view i.e. on the basis of, average and COV, HUL ranked first and it followed by Marico, Cipla etc. Though importance should be given to all the companies selected under this study to improve their financial health.

Reinvestment ratio is the ratio between Increase in fixed assets plus increase in working capital to net income plus noncash expenses minus noncash sales minus dividends. With the help of this ratio, the amount of cash flow that management reinvests in a business can be estimated. High reinvestment ratio might indicate that management is committed to improving the business. It could also portray the excessive amount of investment in fixed assets and working capital.

On the basis of Reinvestment ratio in Table 12, Cipla ranked first and it followed by Lupin, Marico, Alchemist etc. On the other hand, from the point of view of coefficient of variation HUL is scored first and it followed by Cipla, Lupin etc. From overall point of view i.e. on the basis of, average and COV, Cipla ranked first and it followed by Lupin, Marico etc. Though importance should be given to all the companies selected under this study to improve their investment decisions.

Depreciation amortization ratio is the ratio between depreciation expenses plus amortization expenses to operating cash flow. This ratio displays the ratio of cash from operations (CFO) resulting from add backs to the balance sheet of the company. Add backs are used to determine the real state of profitability of the company by adding back expenses items to the net tax operating profit. It is a measurement of financial efficiency. It means how effectively a business or farm is able to generate income. Lower the percentage, strong the ratio. A business should be no higher than $5 \%$ to be considered strong. Any percentage higher than $15 \%$ means that the business may be wearing out its capital to quickly.

It is observed from Table 13 that on the basis of average Depreciation- Amortization Expenses Ratio of Alchemist is highest and it followed by Cipla, Britannia etc. On the other hand, from the point of view of coefficient of variation, HUL is scored first and it followed by Cipla, Lupin etc. From overall point of view i.e. on the basis of, average and COV, Cipla ranked first and it followed by Lupin, HUL etc. Though importance should be given to all the companies selected under this study to improve their financial efficiency.

Debt coverage ratio is the ratio between total operating income and total debt service. This ratio measures in which rates a certain asset's capacity to adequately cover the monthly financial obligations. The ratio measures the capability of the company to pay the annual interest and principal on its debt. If the ratio is below the value of one (1), this will indicate that income generated by the company's asset is in adequate to cover the payments and the operating expenditures related to the particular asset.

From Table 14 it is observed that on the basis of average Debt Coverage Ratio, Cipla ranked first and it followed by Britannia, HUL etc. On the other hand, from the point of view of coefficient of variation, Lupin is scored first and it followed by Alchemist, HUL etc. From overall point of view i.e. on the basis 
of, average and COV, HUL and Britannia ranked first and they followed by Alchemist, Cipla, Lupin etc. Though importance should be given to all the companies selected under this study to improve their adequacy of financial obligation.

Table 15 exhibits that in FMCG sector the correlation coefficients between CFO and CR in HUL and Marico are -0.105 and -0.477 respectively. We can say that in both the companies the liquidity management is good. On the other hand the same in case of Britannia is 0.426. It signifies positive relationship between $\mathrm{CFO}$ and $\mathrm{CR}$.

Table 15 depicts that in case of Pharmaceuticals sector the correlation coefficients between CFO and $\mathrm{CR}$ in Alchemist and Lupin are $-0.005,-0.403$ respectively. It implies the negative association between $\mathrm{CFO}$ and $\mathrm{CR}$ in these two companies. On the other hand the correlation coefficient between CFO and $\mathrm{CR}$ in Cipla is 0.796 which is significant at $1 \%$ level. It implies the positive association between CFO and $\mathrm{CR}$.

Table 15 portrays that in FMCG sector the correlation coefficient between CFO and ITR in HUL, Britannia and Marico are $-0.436,-0.209$ and -0.384 respectively. It signifies the negative relationship between CFO and ITR in these three companies. It indicates that due to poor inventory management system the CFO decreases.

Table 15 depicts that in Pharmaceuticals sector the correlation coefficient between CFO and ITR in Cipla is 0.116. It implies the positive association between CFO and ITR. On the other hand Alchemist and Lupin registered negative correlation between CFO and ITR which are -0.597 and -0.449 respectively. It signifies the negative relationship between CFO and ITR in these two companies. It indicates that due to poor inventory management system the CFO decreases.

Table 15 exhibits that in FMCG sector the correlation coefficient between CFO and DTR in HUL and Britannia are 0.154 and 0.336 respectively. On the other hand the correlation coefficient between CFO and DTR in Marico is -0.025 . It implies the negative relationship between CFO and DTR. It may be due to inefficient debtors' management system which reduces the CFO.

Table 15 portrays that in Pharmaceuticals sector the correlation coefficient between CFO and DTR in Lupin is 0.016. It implies positive relationship between CFO and DTR. On the other hand the correlation coefficient between CFO and DTR in Alchemist and Cipla are -0.018 and -0.553 respectively. It implies the negative relationship between CFO and DTR. It may be due to inefficient debtors' management system which reduces the CFO.

Table 15 shows that in FMCG sector, the correlation coefficient between CFO and ICR in HUL is 0.057. It implies the positive association between CFO and ICR. On the other hand the correlation coefficient between CFO and ICR in Britannia and Marico are -0.244 and -0.483 . It signifies negative association between them. It indicates that the two companies are not generating sufficient revenues to satisfy it interest expenses.

Table 15 shows that in Pharmaceuticals sector, the correlation coefficient between CFO and ICR in Cipla and Lupin are 0.251 and 0.773 respectively and out of which second one is statistically significant at $5 \%$ level. It implies the positive association between CFO and ICR. On the other hand the correlation coefficient between CFO and ICR in Alchemist is -0.545. It signifies negative association between them. It indicates that the company is generating sufficient revenues to satisfy it interest expenses.

From Correlation point of view, we can say that most of the companies selected under this study followed a negative relationship between Cash flow from operating activity and Current Ratio. It supports the theoretically accepted principle that lower the current ratio, higher the Cash flow from operating activity. Again from correlation view point, we can argue that Cash flow from operating 
activity in most of the companies selected under this study negatively associated with Inventory Turnover Ratio. It fails to support the theoretically accepted principle that higher the Inventory Turnover Ratio, higher the Cash flow from operating activity.

From correlation point of view, we can say that most of the companies selected in this study followed a positive relationship between Cash flow from operating activity and Debtors' Turnover Ratio. It supports the theoretically accepted principle that higher the Debtors' Turnover Ratio, higher the Cash flow from operating activity.

The correlation coefficient between CFO and ICR of three companies selected in this study is positive and out of which one is statistically significant at $5 \%$ level and it supports the generally accepted principle that higher the Interest Coverage Ratio, greater the Cash flow from operating activity.

In Table 16, an attempt has been made to assess the influence of profitability, size of the organization and cumulative profitability on cash flow from operating activity (CFO). In this study Return on NetWorth (RONW) has been taken as the measure of Owners' Profitability, Log value of Total Assets has been taken as the measure of the size of the organization and Shareholders' Fund has been taken as the measure of cumulative profitability. The linear regression equation has been fitted in this study is CFO $=\mathrm{a}_{0}+\mathrm{a}_{1}$ RONW $+\mathrm{a}_{2}$ Size of Org. $+\mathrm{a}_{3}$ Shareholders' Fund, where, $\mathrm{a}_{0}$ is the value of intercept term(constant) and $\mathrm{a}_{1}, \mathrm{a}_{2}$ and $\mathrm{a}_{3}$ are the slope of the line i.e. regression coefficient of CFO on RONW, Size of the Organization and Shareholders' fund. This regression equation has been tested by ' $t$ ' test.

Table 16 depicts that in case of FMCG sector, for one unit increase in RONW the CFO of HUL stepped up by 19.87 units. The Table also shows that for one unit increase in the Size of the Organization, the CFO of HUL stepped down by 1011.30 units. From Table 16, it is found that for one unit increase in Shareholders' Fund, the CFO is increased by 2110.41 units. It implies that the influence of Size of the Organization on CFO is negative but the influence of RONW and Shareholders' Fund on CFO is positive. The coefficient of determination $\left(\mathrm{R}^{2}\right)$ makes it clear that $45.9 \%$ of the variation of the company's CFO is accounted for the variation in RONW, Size of the Organization and Shareholders' Fund.

It has been found from Table 16 that for one unit increase in RONW, the CFO of Britannia decreased by 4.86 units. Table 16 shows that for one unit increase in Size of the Organization the CFO of Britannia stepped up by 502.75 units. The Table also depicts that for one unit increase in Shareholders' Fund, the CFO is decreased by 181.343 units. It signifies that the effect of RONW and Shareholders' Fund on CFO is negative. But the effect of Size of the Organization on CFO is positive. The coefficient of determination $\left(\mathrm{R}^{2}\right)$ makes it clear that $32.1 \%$ of the variation of the company's CFO is accounted for the variation in RONW, Size of the organization and Shareholders Fund.

It is found from Table 16 that for one unit increase in RONW, the CFO of Marico stepped down by 8.37 units. The above mentioned table also shows that for one unit increase in Size of the Organization the CFO increased by 1132.89 units which is statistically significant at $5 \%$ level. Table 16 depicts that for one unit increase in Shareholders' Fund, the CFO of Marico, stepped down by 1134.17 units. It implies that the influence of RONW and Shareholders Fund on CFO is negative whereas Size of the Organization positively influenced the CFO of the company. The coefficient of determination $\left(\mathrm{R}^{2}\right)$ makes it clear that $59.5 \%$ of the variation of the company's CFO is accounted for the variation in RONW, Size of the Organization and Shareholders' Fund.

Table 16 depicts that in case of Pharmaceuticals sector, for one unit increase in RONW the CFO of Alchemist go down by 1.271 units. The Table also shows that for one unit increase in the Size of the Organization, the CFO of Alchemist stepped up by 18.34 units. From Table 16, it is found that for one unit increase in Shareholders' Fund, the CFO is decreased by 19.08 units. It implies that the influence 
of RONW and Shareholders' Fund on CFO is negative but the influence of Size of the Organization on CFO is positive. The coefficient of determination $\left(\mathrm{R}^{2}\right)$ makes it clear that $20.8 \%$ of the variation of the company's CFO is accounted for the variation in RONW, Size of the Organization and Shareholders' Fund.

It has been found from Table 16 that for one unit increase in RONW, the CFO of Cipla increased by 2.482 units. Table 16 shows that for one unit increase in Size of the Organization the CFO of Cipla stepped down by 3059.87 units. The Table also depicts that for one unit increase in Shareholders' Fund, the CFO is increased by 3989.74 units. It signifies that the effect of RONW, Shareholders' Fund on CFO is positive whereas the influence of Size of the Organization on CFO is negative. The coefficient of determination $\left(\mathrm{R}^{2}\right)$ makes it clear that $81.4 \%$ of the variation of the company's CFO is accounted for the variation in RONW, Size of the organization and Shareholders Fund.

It is found from Table 16 that for one unit increase in RONW, the CFO of Lupin stepped up by 8.085 units. The above mentioned table also shows that for one unit increase in Size of the Organization the CFO decreased by 1084.63 units. Table 16 depicts that for one unit increase in Shareholders' Fund, the CFO of Lupin, stepped up by 1086.53 units which is statistically significant at $5 \%$ level. It implies that the influence of RONW and Shareholders Fund on CFO is positive whereas Size of the Organization negatively influenced the CFO of the company. The coefficient of determination $\left(\mathrm{R}^{2}\right)$ makes it clear that $83.6 \%$ of the variation of the company's CFO is accounted for the variation in RONW, Size of the Organization and Shareholders' Fund.

From the linear regression equation it is quite clear that out of six companies selected under study in 03 companies (HUL, Cipla and Lupin) the effect of RONW on CFO is positive. On the other hand, out of six companies selected under study, in 03 companies (Britannia, Marico and Alchemist) the effect of Size of the Organization on CFO is positive, where one is statistically significant at $5 \%$ level. Out of six companies selected under this study, in 03 companies (HUL, Cipla, Lupin) the influence of Shareholders' Fund on CFO is positive.

\section{Conclusions}

Let us discuss the performance of the companies on the basis of selected cash flow ratios. We measured the performance of 15 companies (three companies each from IT, Consumer Durable, FMCG, Pharmaceuticals and Retail sectors) with the help of cash flow ratios. This discussion makes our study fruitful. From liquidity point of view the performance of Marico is the best and it followed by Britannia, HUL etc. of the selected companies under study. In case of solvency criteria, the performance of HUL and Marico is the best and it followed by Wipro, Britannia, Hawkins, Cipla etc. of the selected companies under study. From the profitability view point HUL is the best and it followed by Wipro, Cipla etc. of the selected companies under study. Efficiency ratios are used for measuring the quality of particular business receivables and efficiency by which that business utilizes its assets. It is used for measuring the consistency in paying financial obligations, 'over' or 'under' trading of company's equity and the company using funds sourced outside the revenue generating sources of the company. On the basis of different efficiency ratios the performance of HUL is best and it followed by Wipro, Marico, Cipla etc. of the selected companies under study.

Sufficiency ratios are used to measure the capacity of the business to settle financial requirement. This ratio is used to judge the insolvency of the companies, financial health of the companies, efficiency of the management regarding investment decisions, financial efficiency and company's assets adequateness etc. On the basis of different sufficiency ratio the performance of HUL, Cipla and Raymond are jointly the best and it followed by Lupin, Wipro, Asian Electronics Ltd., Marico etc. of the selected companies under study. From over all point of view, the performance of FMCG sector is the best and it followed by IT sector, Pharmaceuticals sector etc. of the selected sectors under study. If 
we measure the individual performance, the performance of HUL is the best from different angels under consideration and it followed by Wipro, Cipla from the selected companies under study.

The study recommended policy of looking at profitability in a holistic manner and working towards identifying these primary variables that influences profitability of enterprises. It is evident that cash flow has significant relationship with profitability for this segment of firms sampled. Cash Flow Ratios are the better measures of Liquidity, Solvency, Efficiency, Sufficiency and Profitability than Traditional Ratios.

\section{References}

Ahmed, A. S., Billings, B. K., Morton, R. M., \& Stanford-Harris, M. (2002). The role of accounting conservatism in mitigating bondholder-shareholder conflicts over dividend policy and in reducing debt costs. The Accounting Review, 77(4), 867-890.

Albrecht, W. S. (2003). Fraud Examination Mason, Ohio, Thomson and South- Western.

Albrecht, W., Stice, J., Stice, E., \& Swain, M. (2007). Accounting: concepts and applications. Cengage Learning.

Barth, M.E., Cram, D.P. \& Nelson, K.K. (2001). Accruals and prediction of future cash flows. The Accounting Review, 76(1), 27-58.

Bebchuk, L. A., \& Cohen, A. (2005).The costs of entrenched boards. Journal of Financial Economics, 78(2), 409-433.

Bhagat, S., Black, B., \& Blair, M. (2004).Relational investing and firm performance.journal of Financial research, 27(1), 1-30.

Bodie, Z., Kane, A., \& Marcus, J. (2004) Essentials of Investments (5th Ed. Irwin)

Carslaw, C. A., \& Mills, J. R. (1991). Developing ratios for effective cash flow statement analysis. Journal of Accountancy, 172(5), 63.

Cremers, K. J., \& Nair, V. B. (2005).Governance mechanisms and equity prices. The Journal of Finance, 60(6), 2859-2894.

Das, S (2017). Measuring the performance through cash flow ratios- A study on CMC. Journal of Commerce and Accounting Research, 6(4), 1-7.

DeFond, M. L., \& Hung, M. (2003). An empirical analysis of analysts' cash flow forecasts. Journal of Accounting and Economics, 35(1), 73-100.

Epstein, B. J., \& Jermakowicz, E. K. (2008). Wiley IFRS 2008: Interpretation and Application of International Accounting and Financial Reporting Standards 2008. John Wiley \& Sons.

Fabozzi, F. J., Gupta, F., \& Markowitz, H. M. (2002).The legacy of modern portfolio theory. The Journal of Investing, 11(3), 7-22.

Giacomino, D. E., \& Mielke, D. E. (1993). Cash flows: Another approach to ratio analysis. Journal of Accountancy, 175(3), 55.

Gompers, P., Ishii, J., \&Metrick, A. (2003).Corporate governance and equity prices. The quarterly journal of economics, 118(1), 107-156.

Helen, K. (2002). The effect of lenders decision. The International Journal of Accounting, 37(3), 347362.

Jones, M.J. (1997). Critical appraisal of the cloze procedure's use in the accounting domain. Accounting, Auditing and Accountability Journal 10(1), 105-128.

Macve, R. (1997). Accounting for environmental cost. National Academy Press.

McClure, B. (2008). Earnings: Quality means everything. New York: McGraw-Hill.

Mills, J., \& Yamamura, J. H. (1998). The power of cash flow ratios. Journal of Accountancy, 186(4), 53.

Paterson, P. P., \& Drake, P. P. (1999).Analysis of financial statement. London: Wiley.

Pereiro, L. E. (2002). Valuation of companies in emerging markets: a practical approach (Vol. 156). John Wiley \& Sons. 
Rose, C. (2007). Does female board representation influence firm performance? The Danish evidence. Corporate Governance: An International Review, 15(2), 404-413.

Stammerjohan, W. W., \& Nassiripour, S. (2001). Predicting SFAS 95 cash flows: the relative importance of prior earnings, cash flows, and accruals. Accounting Enquiries, 10(1), 87.

Wells, J. T. (2005). Principles of Fraud Examination, Hoboken, New Jersey: John. 


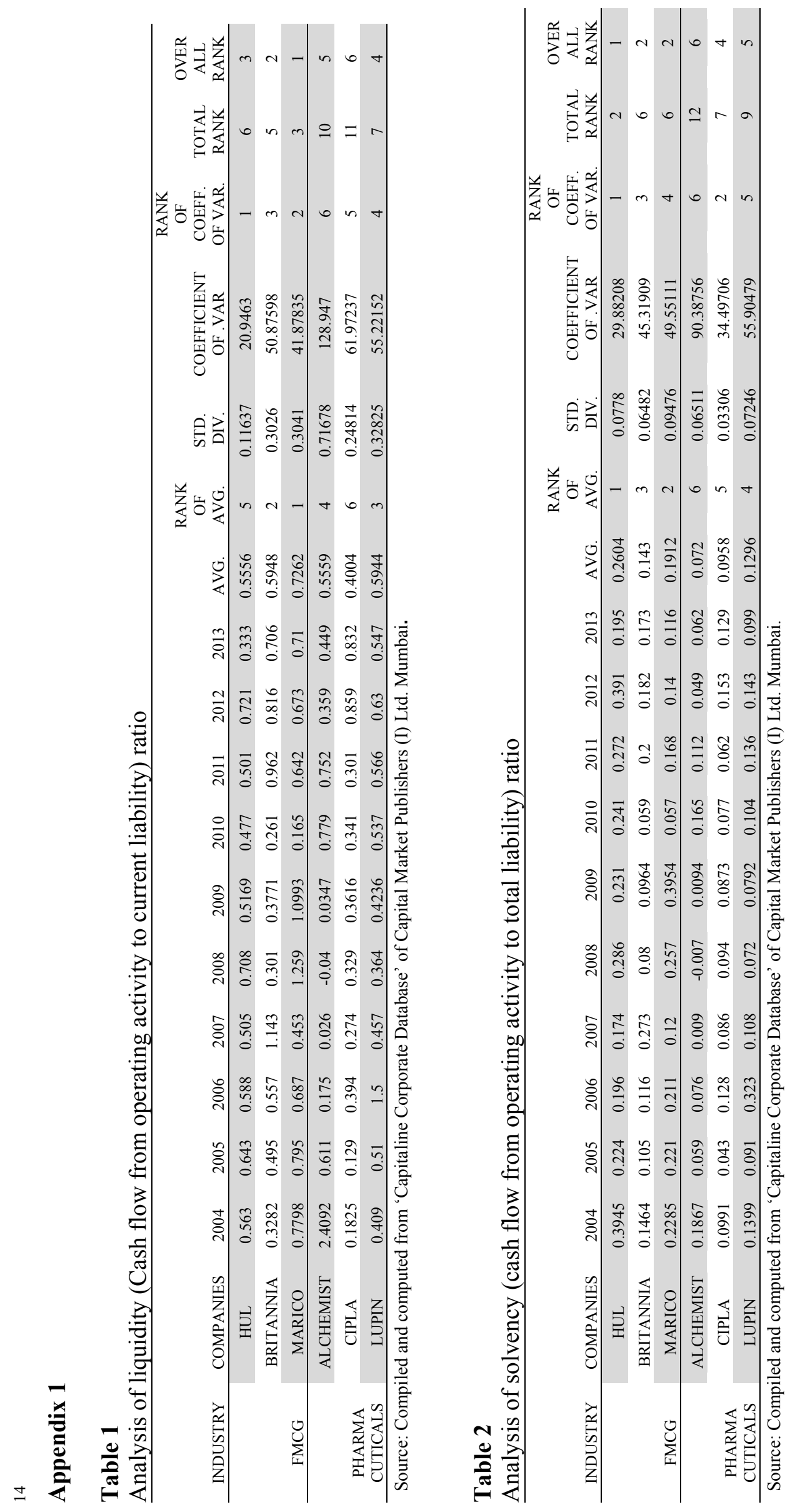




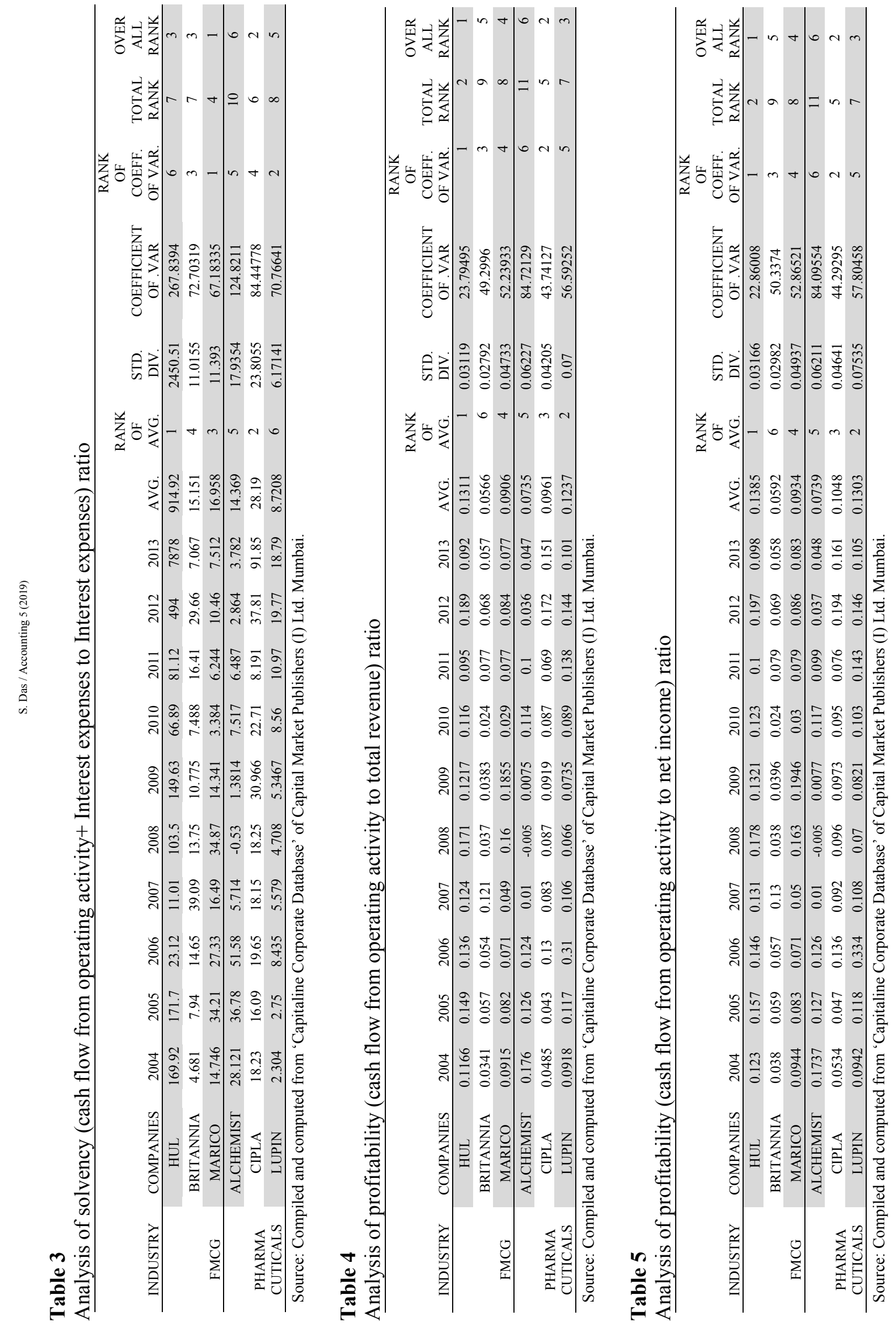



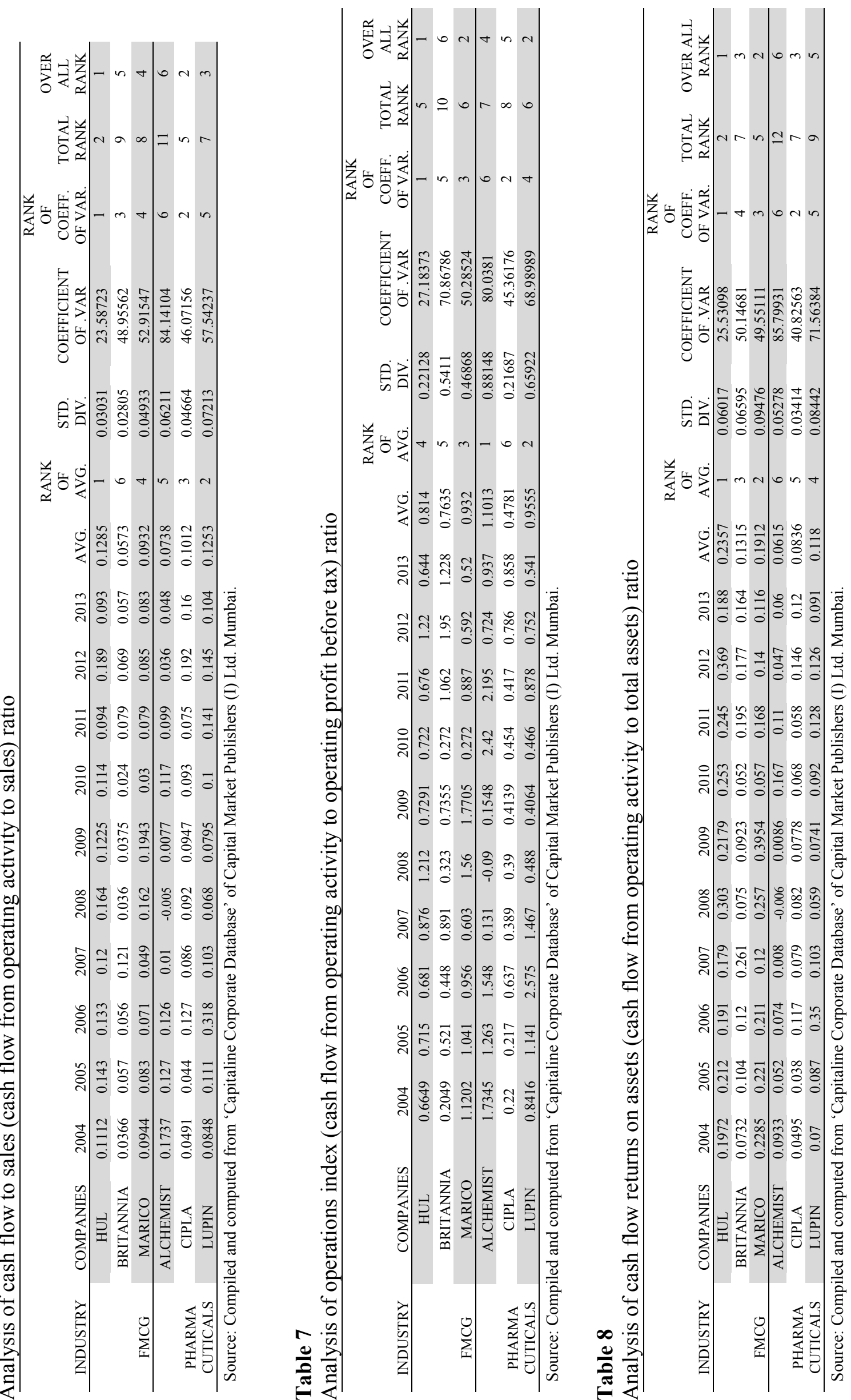

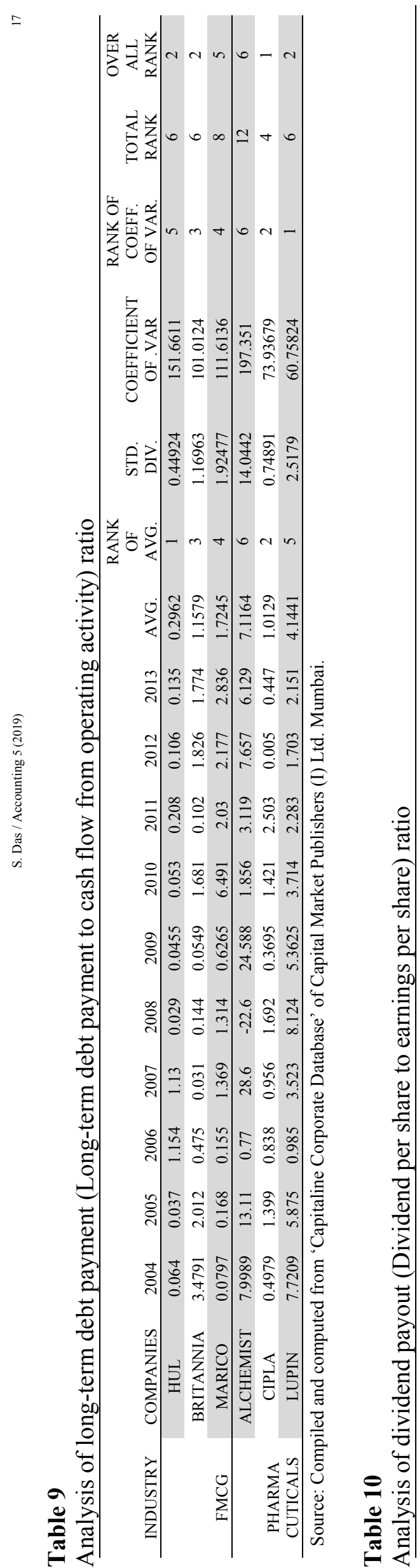

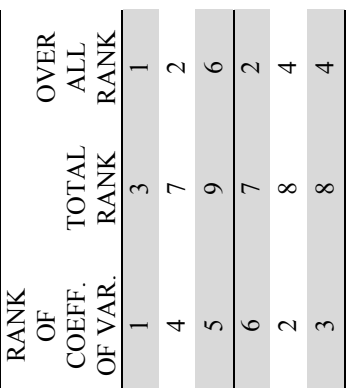

学

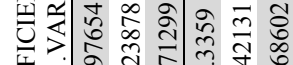

蹓

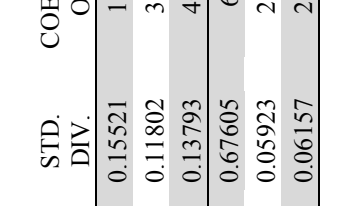

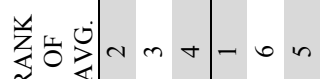

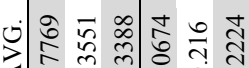

यदि

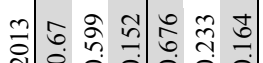

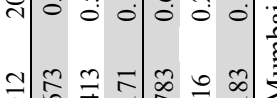

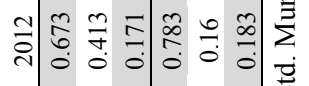

चี่

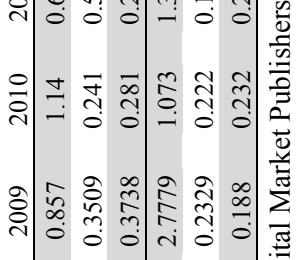

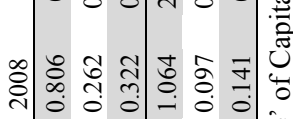

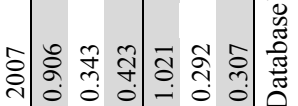

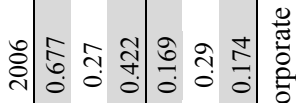

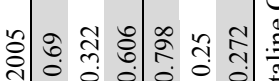

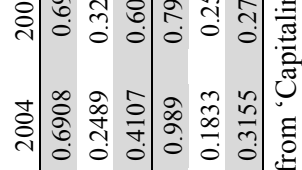

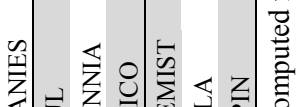

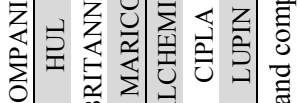

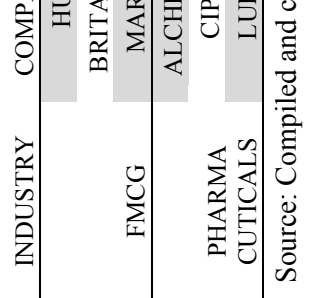



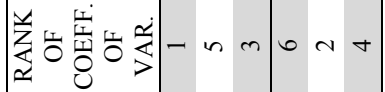

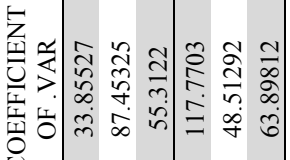

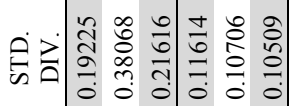

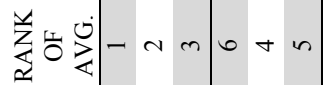

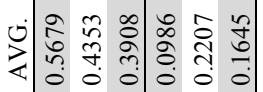

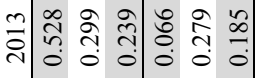

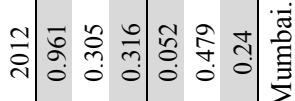

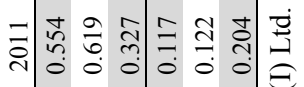

귄

○े

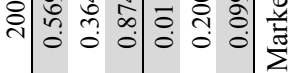

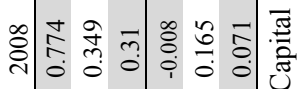

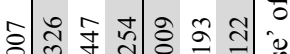

กิ

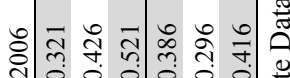

-

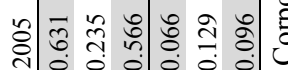

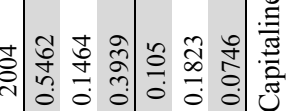

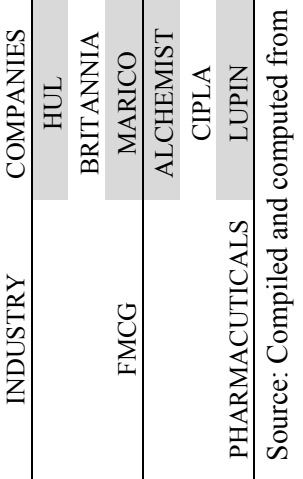




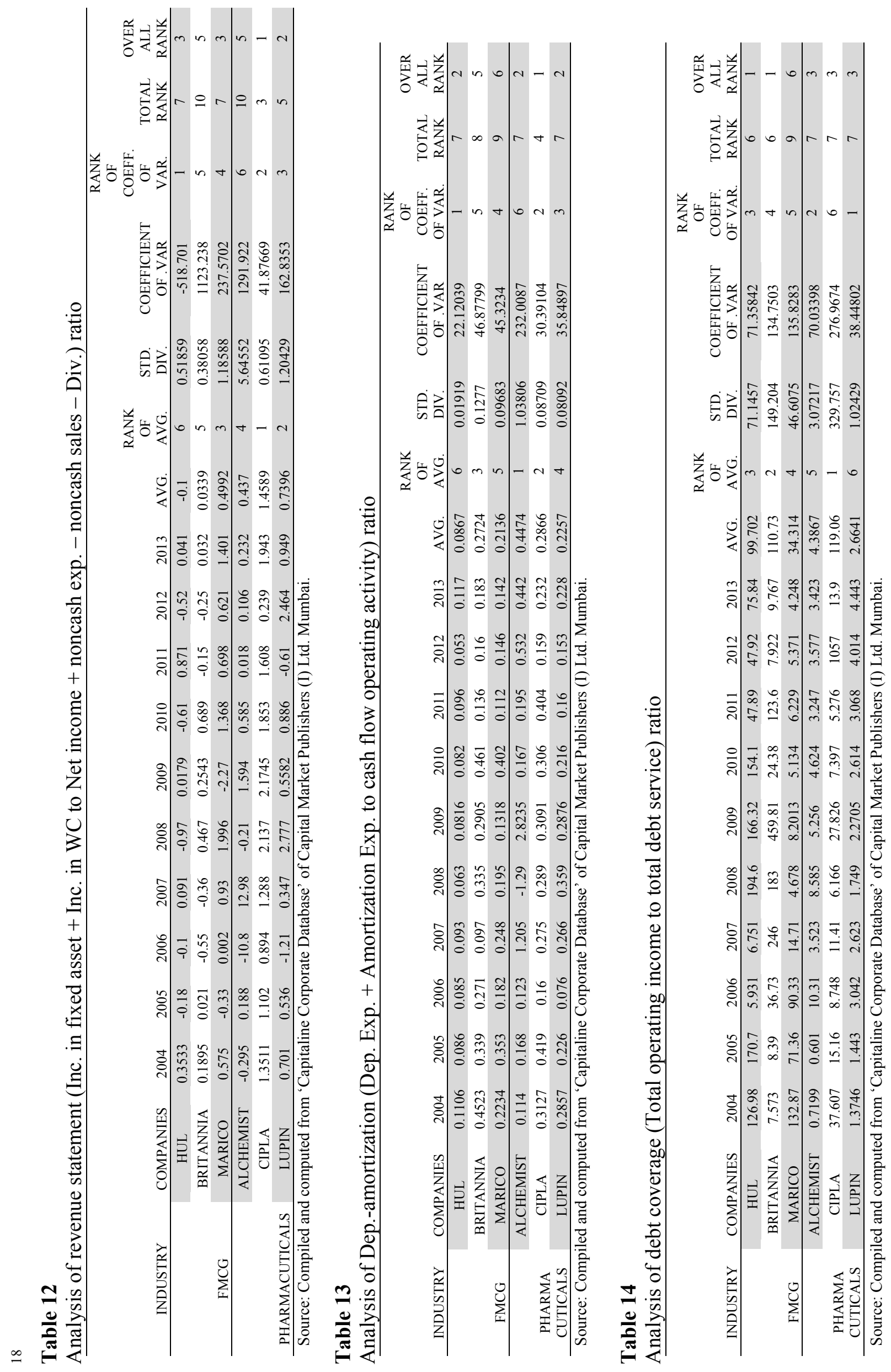




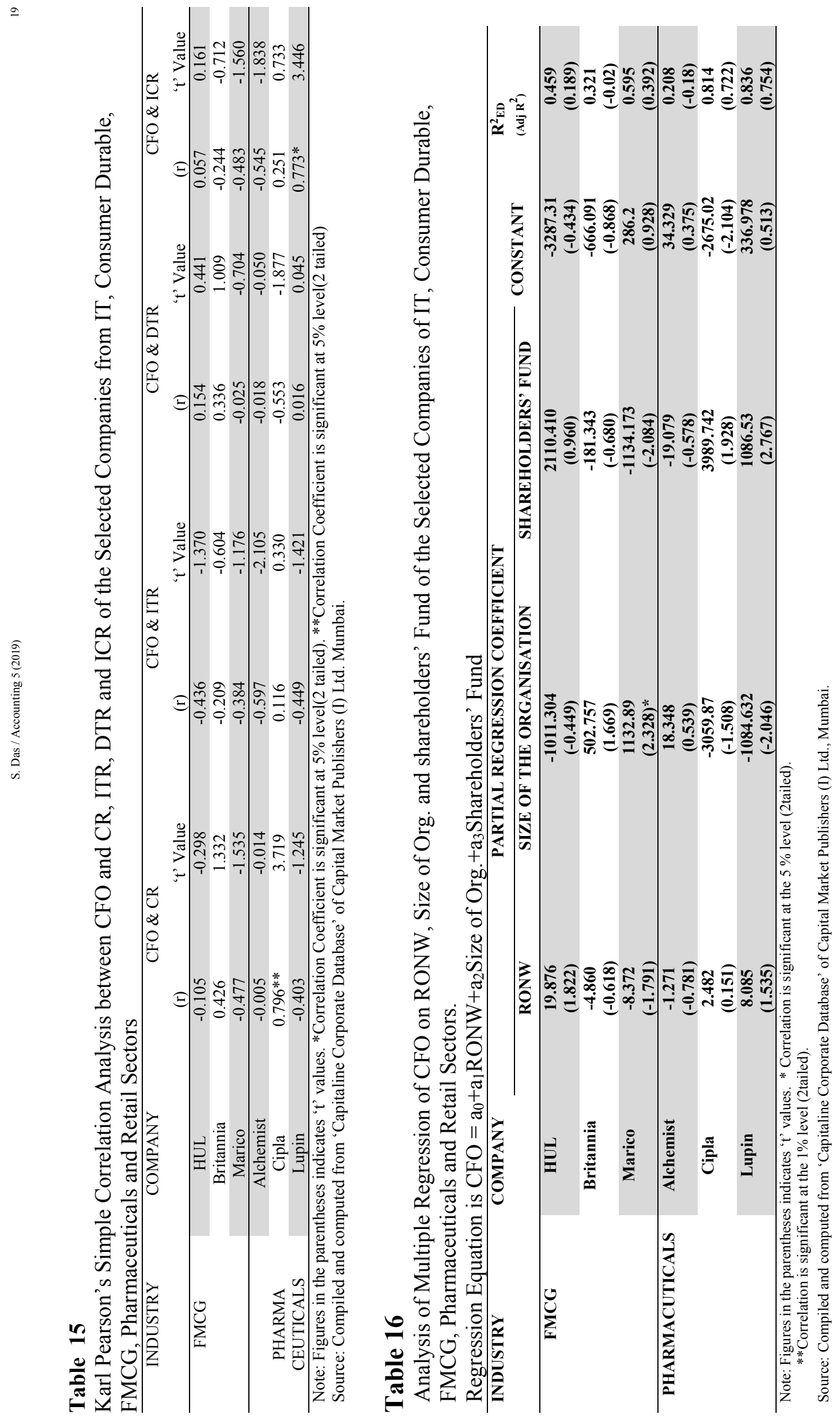




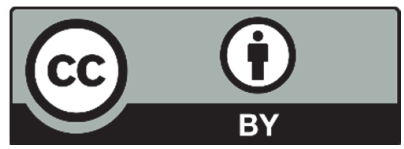

(C) 2019 by the authors; licensee Growing Science, Canada. This is an open access article distributed under the terms and conditions of the Creative Commons Attribution (CC-BY) license (http://creativecommons.org/licenses/by/4.0/). 